\section{Africa and the U.S. Higher Education Market}

\section{Damtew Teferra}

Damtew Teferra is lead researcher of the African Higher Education Project at the Center for International Higher Education at Boston College. His email is <teferra@bc.edu>.

$\mathrm{T}$ he United States annually hosts over half a million students and 79,000 researchers from around the world. In 2000, over 34,000 students and close to 2,300 scholars from Africa traveled to the United States, with students from Kenya, Nigeria, Ghana, Egypt, and South Africa were in the lead. Compared with other continents and regions, Africa has the smallest number of students to the United States.

About 140,000 foreign students study in Germany, less than 10,000 of them from Sub-Saharan Africa. France is host to more than 110,000 international students: more than 50 percent come from Africa, which marks the largest percentage of African student population studying in the developed world. The United Kingdom, currently with over 200,000 foreign students, is gearing up to boost its total global higher education market share to 25 percent by 2005. In 2000, 10 percent of the total foreign student population in the United Kingdom came from Africa.

Many countries compete in the international higher education market to attract students and scholars from all over the world. Given the stringent visa procedures, security concerns, and the high cost of higher education in the United States (and, to a lesser extent, the United Kingdom), Canada, Australia, and New Zealand are planning to increase their share of the international knowledge market. Japan, Russia, India, and South Africa are emerging as regional education providers.

\section{Many countries compete in the interna- tional higher education market to attract students and scholars from all over the world.}

\section{Constraints on African Students}

Overall, the capacity of many governments, universities, and other institutions in Africa to send their nationals abroad for advanced training has diminished significantly. The nature of the market is such that most of Africa and other poor countries have remained and will remain at the margins of the international knowledge landscape. Out of over 100,000 international students in Canada in 2001, only 309 were from Africa. This figure, which equalled over 2,400 in 1991, declined with diminishing resources from official Canadian development assistance. Even in France, with the highest percentage of students from Africa, over 60 percent come from the three Maghreb countries of Algeria, Morocco, and Tunisiawhile the Sub-Saharan countries are underrepresented.

\section{A number of restrictive measures have recently been imposed in the United States that disproportionately affect African students:}

In the face of declining national capacity to sustain graduate training in Africa, many postgraduate students pursue studies in the United States through assistantship arrangements: students provide teaching and research services to institutions in exchange for tuition remissions and stipends.

Here, too, a number of restrictive measures have recently been imposed in the United States that disproportionately affect African students: stepped up scrutiny of incoming students, new laws and regulations to track students, additional visa-processing fees, and extended waiting periods for granting visas.

Even before September 11, the acquisition of U.S. travel documents for African students-particularly those from Sub-Saharan Africa- has often been a difficult, costly, and haphazard process. Visa processing fees charged to individuals are expensive given African salaries, and this is particularly so when the process drags on and consulates impose fees for every single visitation. The newly introduced $\$ 95$ fee on student visas adds an extra financial burden on applicants from poor countries.

September 11 has also changed the manner in which visas for international students are renewed. Before September 11, students often traveled to neighboring countries, such as Canada or Mexico, to renew their visas; this arrangement has now been curtailed and many students are required to return to their home countries. This imposes a heavy burden on students from Africa, economically and logistically. The customary experience has been that students did not need to renew their visas as long as they remained in the United States. However, students, particularly those in graduate programs, may have to travel to other countries- to attend conferences and meetings, present research work, visit institutions, and collect data and do research. The current situation requiring foreign students either to return home to renew their visas or stay put in the United States during the course of their studies (once their visas expire) does not provide much of a fair choice, particularly for (SubSaharan) African students of limited resources. 
Even when travel funds are not an insurmountable barrier, the unpredictable encounters at U.S. embassies in home countries are a challenge. Even before the current heightened scrutiny, consular officials exercised considerable discretion, and the fairness of their actions has often been questioned. African students and scholars have often complained of unfair treatment and groundless rejection by consular staff. A recent bribery scandal involving more than 70 student visas processed at the U.S. embassy in Qatar adds another dimension to the problem. Generally, African students face very high hurdles and scrutiny in obtaining and renewing visas and interacting with American officialdom.

\section{Recruitment Disincentives}

The repercussions of September 11 will impinge on the internationalization of U.S. higher education, and this may have ramifications on international intellectual communities. The impact is, however, felt disparately across different constituencies and countries.

The increasingly complex and expensive visa processing and verification process may dampen the interest of many U.S. institutions in recruiting international students. Institutions may simply feel such recruitment is too complex and troublesome. Even those institutions active in recruiting international students may not find it worthwhile to spend their resources on some of the more marginal markets.

With its abundant institutions and programs, diverse scholarly and employment opportunities, cosmopolitan ambience, diverse society, and English-language environment, the United States remains the most attractive destination for international students and scholars. But the escalating cost of higher education, the increasing monitoring of international students and scholars, tight visa procedures, as well as the aggressive marketing efforts by other countries to attract foreign students, might displace the United States as the preferred destination. For many in Africa, however, the diverse educational and employment opportunities in the United States will still continue to attract students and scholars.

\section{The increasing monitoring of international students and scholars might displace the United States as their destination.}

\section{Conclusion}

The tightening up of U.S. regulations on student admissions, long waiting periods and high fees for visas negatively affect scholarly communities at the margins that depend on assistantships and scholarships. Much of Africa finds itself in this position. The current situation, stimulated in part by the events of September 11, do significant damage to the educational relationship between the United States and developing countries generally and Africa in particular. This is especially unfortunate as it will weaken America's relations with an important part of the world and will undermine Africa's goal to build its academic and scientific capacities.

\section{News of the Center and the Program in Higher Education}

The Center will cosponsor, with Nagoya University in Japan, a conference on "The Past and Future of Asian Universities," on December 16-17, 2002, at Nagoya University. This working conference will discuss papers concerning 12 Asian countries. The papers will later be published in book form. Part of the conference will include an open forum on Asian higher education sponsored by the Japanese Ministry of Education. The conference is funded by the Toyota Foundation and the Japanese Ministry of Education. It is coordinated by Philip G. Altbach and Toru Umakoshi.

The Center welcomes new and returning staff members. Hong Zhu joins the doctoral program in higher education and the Center from Peking University in China, where she obtained a master's degree in higher education and was assistant to the executive vice president. Robin Helms is working on an MBA and a doctorate in higher education and will be assistant editor of International Higher Education. Alma Maldonado-Maldonado will continue with her work on the Center's private higher education initiative as she pursues her dissertation research on Latin American higher education research. Roberta Bassett continues as managing editor of the Review of Higher Education. Francesca Purcell and Jef Davis will be assisting with Center projects. Alexei Kuraev will be working on the internationalization of higher education in Russia.

The Center's cooperative initiative on private higher education with the State University of New York at Albany continues. We are currently working on a major bibliography on private higher education and will develop a website on the topic. This work and other Center activity are being supported by the Ford Foundation.

Center director Philip G. Altbach recently participated in the China-Foreign University Presidents Conference in Beijing, where he gave a talk on future directions for Asian higher education. He will be speakng at a conference on globalization and Catholic higher education in December 2002. The conference is cosponsored by the Vatican and the International Federation of Catholic Universities. 